\title{
Democracy in Pakistan: Value Change and Challenges of Institution Building
}

\author{
SAEED SHAFQAT
}

\section{INTRODUCTION}

Democracy as a system of governance and interest representation demands respect for dissent and opposition. It recognises the principle of majority rule and guarantees protection of minorities. Democracy also builds faith in electoral contestation to gain public office and gives legitimacy to political parties as primary instruments for acquisition and transfer of power from one set of individuals to another. Unfortunately, despite the significance of the above elements, no serious studies have been undertaken on Pakistan's experimentation with democracy. Given a history of weak party system and prolonged military rule, most of the studies focus on the military, political parties, constitutional history, or in a descriptive way, attribute the failure of democracy to the inadequacies of the politicians [Ahmed (1987); Rizvi (1987); Callard (1957) and Afzal (1976)]. It is only recently that some theoretically meaningful and rigorous empirical writings have appeared on elections, procedures and practices of electoral contestation and on problems of transition from authoritarian regimes towards democracy [Waseem (1989); Wilder (1995); Talyor (1992); Rais (1997) and Shafqat (1997)].

It merits attention and recognition that among the Muslim states and developing world, Pakistan is one of those few states, where people have shown vigour and some vitality to adopt a democratic parliamentary system and through popular mass movements demonstrated disapproval of military dictatorships. An enduring feature of Pakistani culture, history and politics has been an aspiration for democracy [Hugh and Rose (1997)]. The passion for democracy continues to resurge, despite ethnic, social class, religious cleavages, strong authoritarian tendencies and prolonged military rule. There is no gainsaying that cultural and structural conditions weigh heavily against the promotion of democratic processes and institutions in Pakistan [Taylor (1995); Embree (1987); Gardezi (1983); Jalal 
(1995) and Waseem (1989)]. The civil society has expanded, but is still weak, inspite of a number of non-governmental groups, formal associations, human rights organisations, autonomous bodies that have emerged over the years. Even the size and scale of political parties has risen. A number of regional parties, e. g., Awami National Party (ANP) and Baloch National Party (BNP) and Muthida Qaumi Mahaz (MQM) did gain representation in the federal structure during 1997-98. These were positive indications and generated hope in the democratic potential [Inayatullah (1997)]. However in the past one year, the PML (N) Government's attempt to impose a majoritarian view of democracy (as manifested through the announcement of Kalabagh Dam, 15th Amendment and imposition of governor's rule in Sindh) has roused skepticism among the smaller provinces and encouraged the formation of Pakistan Oppressed Nations Movement (PONM).

The prolonged military rule (1977-1988), obliterated democratic norms, stifled democratic values, yet aspiration for democracy continues to persist. For almost a decade (1988-1999) Pakistan has sustained a transition to parliamentary democracy. This has been the longest period of civilian led regimes, although, none of the elected governments have been able to complete its five year term in office. It is encouraging to note that the principle of electoral competition has gained strength. Electoral procedures have acquired stability. Despite presidential interventions (1988, 1990, 1993 and 1996) and dissolution of the assemblies, democratic creed has survived. Local Bodies Elections (May 20, 1998) in Punjab, (notwithstanding violence and allegations of rigging), reflect a growing confidence in the electoral principle. Similarly in Balochistan Local Bodies elections have been held (March, 1999). Ironically, despite frequency of electoral competition, political leaders have not been successful in promoting an environment that would encourage the growth of democratic norms and civility. Popular aspiration for democracy has not received a corresponding support from the elected political leadership. Therefore, a strong tendency towards illiberal usages of democracy continues to threaten prospects of democratic consolidation. These contradictory processes are transforming the political landscape in Pakistan.

\section{SOME CRITICAL QUESTIONS}

How should we analyse this relationship between democratic transition and building of political institutions? What are the social forces of resistance and support to democracy? What is the role of political leaders and political parties in promoting or hampering democratic development in Pakistan?

To respond to these questions, this paper would identify, analyse and evaluate the processes of value change and political transformation by focussing on four themes. (1) Electoral contestation and supremacy of the political—The elected public official; (2) electoral competition: Politics and District administration; (3) Behavioural patterns of political leadership, socioeconomic profile of the 
parliamentarians and their disabilities to build parliamentary democracy; and (4) Political parties and challenges of democratic development.

In this paper, at the theoretical level, an argument would be developed that democracy is a system of governance and interest representation in which supremacy of laws and procedures is a prerequisite. That the political leadership, élites and powerful interest groups need to strive, not only to uphold the rule of law, but also demonstrate respect for these and seek observance and compliance from a wider segment of citizens.

Constructing and promoting democracy is not an easy task, it requires patience, time and, most importantly, a consensus among the powerful groups and élites in a society on the desirability of rule of law and governance through the consent of the people. Thus, the onus of responsibility for constructing democracy, promoting democratic norms, and institutionalising democratic practices and principles is on the élites. Political leaders and élites through their actions and conduct, influence the formation of democratic norms at the popular level. A large number of people in a society have to accept and demonstrate faith in democratic principles. In societies, where a gap between the élites and representatives of the people on professed principles of democracy and their actual conduct widens, people begin to loose faith in democracy. This study would sharpen our focus on this "gap" problem.

\section{BUILDING DEMOCRACY WITHOUT DEMOCRATS?}

For the purpose of this study political leadership is defined to convey the actions, policies, orientation, conduct and behaviour of top decision-makers of the political party in power, its allies and opposition party leaders. Focus on political leadership, as a unit of analysis, is meaningful and necessary because there is a growing consensus among public advocates and scholars that an "effective and committed leadership" does act as a facilitator for consolidating democracy. In societies like Pakistan, where institutional development has remained weak, selfenriching and reckless policies of political leaders could further erode the institutions, therefore it becomes imperative not only to analyse the actions and policies of the political leadership, but also to sensitise them about the consequences that their decisions may have for society and the political system.

In this context, it would be argued that the greatest stumbling block in democratic development has been the contradictory behaviour and attitude of Pakistani political leaders and élites. Despite making struggle for the restoration of democracy, they have failed to build a legal framework, create a pro-democracy environment, and most importantly, develop a policy framework in which conflicts may be resolved through negotiations, by making bargains, and by building consensus. Democracy cannot grow and function in the absence of élite-consensus. Those political leaders and élites who, while struggling for democracy, expressed democratic sentiments, upon assuming power, changed and demonstrated 
authoritarian tendencies. They pursued or adopted policies that strengthened authoritarian attitudes rather than promote democratic norms, flout rule of law and defy tolerance of any political opposition. As a result of these tendencies, there is a growing skepticism about the sustainability of democracy. The disappointment is not with democracy as a form of government but with the conduct and behaviour of parliamentarians and political parties who are expected to make democracy work.

The foundations of democracy are built on acceptance of rule of law among the wider number of members of the civil society. It is not to trivialise the significance of culture, social structure and level of economic development. Favourable disposition of these factors, certainly helps and brightens prospect of democratic development. It is only in this context that the rule of law, respect for procedures, fairplay and justice, equality before law-irrespective of caste, creed, religion or status, are the principles on which democracies are built. Democracy thrives on competition, fairplay and encourages merit. 'Spoil' system or distribution of rewards-i.e., extension of patronage to supporters of a political party is one small aspect of democratic process. Because in a democracy political parties compete to gain power to pursue and implement specific policies for public good. The expectation is that a particular party will be in power for a certain period of time. Therefore, in order to implement the policies, that it advocates, the groups that it represents, it needs political activists and ideologues to achieve its goals. Thus, for political parties, patronage system and democracy grow side by side. On the other hand, electoral process and political parties are not expected to obstruct merit, achievement-orientation or citizen's right to compete, excel and advance their interests. In a number of developing countries, like Pakistan, where aspiration for democracy is strong, but pro-democracy groups, and political parties are weak, retaining this distinction between spoil system and pursuit of merit becomes complicated. This complication rouses skepticism—about civil society's ability to respect the rule of law.

\section{(1) Electoral Contestation and Supremacy of the Political- the Elected Public Official}

Do elections promote supremacy of the elected public official over the bureaucracy? Let me examine and weave a relationship between electoral process and transformation of administrative institutions.

Elections and electoral process has brought about a change in the attitude of political parties and their leaders. Until the first general elections of 1970, the political leaders and parties generally accepted the superiority and lawful authority of the bureaucratic élites. Between 1947-1970, there were rarely any demands for posting and transfers of the public officials. However, once the PPP, assumed power in December 1971, under the leadership of Zulfikar Ali Bhutto, the elected public 
officials began to establish supremacy of the elected on the non-elected public officials. Bhutto redefined the basis of political leader-bureaucracy relationship.

The 1973 Administrative Reforms were a turning point in the history of Pakistani bureaucracy [Kennedy (1987)]. Through these reforms, Bhutto sought to establish civilian supremacy over bureaucracy. His goal was that, at the macro-level, the bureaucracy should accept the supremacy of the political leadership and representative institutions. He sought to alter the structural balance in favour of the political leadership. He did not encourage interference in the workings of government at the micro level. Bhutto government (1971-77) could be criticised for his over-enthusiasm in venturing to establish political dominance over state institutions (i.e., military and bureaucracy). Nevertheless, Bhutto's approach gave a new sense of confidence to political parties and their leaders, who in subsequent years, began to aspire for civilian supremacy over the state institutions. This ushered in a change in political values. General Zia-ul-Haq's martial Law (1977-1985) attempted to reverse this trend, by delegitimising politics at the national level and by encouraging Local Bodies elections. Thus, Zia attempted to restore the colonial model of politics, where local influentials could be co-opted to pursue political ambitions under the guidance and patronage of district administration, i.e., ensuring continuity of bureaucratic authority on policy and administrative matters. Party-less Local Bodies elections were held in 1979, 1983, 1987. The regime's strategy was not only to initiate and promote new individuals and groups into the political arena, but also to delegitimise the role and significance of leaders who had become members of the parliament on the basis of affiliation with political parties. In pursuance of this objective, Zia regime formulated a policy through which members of the Local Bodies were given developmental grants to improve upon health, education, roadbuilding and utilities development net works in their constituencies. Zia met limited success, but, in the process, facilitated the emergence of local influentials in the national political arena. As soon as the 1985 party-less elections gave birth to parliament and restored the democratic process, the elected public officials began to work for their supremacy with new zeal. The government of prime minister Mohammed Khan Junejo upgraded the same programme of granting a developmental grant of Rs 50 lakh to each Member of the National Assembly. This development grant was funnelled through Public Works Department (PWD), Local Government, Communication and Works Department (C and W) and the district administration. Thus, emerged a new nexus of politician and administrator. In a number of instances, these grants were not properly utilised, funds were misappropriated and in some cases were usurped by politicians for self-enrichment. At the popular level, democracy was seen as promoting corruption and not development. Armed guards and Pajeros emerged as new symbols of power and authority in the rural setting. Thus, with each electoral contest, the candidates not only displayed new symbols of power, but the voters also began to demand more 
compensation for their votes. The contestants to the parliament came under pressure from their constituents to obtain jobs, resolve their problems and secure development. The voters also saw elections as an opportunity to advance their interests. Thus a value change occurred.

Electoral experience of Pakistan during 1985-1997, reveals a pattern; after each election (i.e. 1988, 1990, 1993, 1997), the political leaders not only gained

greater autonomy, but become more vigorous in pursuing their supremacy. In the process, they were driven by the demands of their constituents and personal interest (i.e. providing jobs to members of their constituency, promoting some developmental work through administrative help, seeking the removal of grievances of their voters and developing a personal connection with the public officials working in their subdivision/district). Interestingly, the electoral process has accentuated two trends. First, political interference in the administration has increased. Secondly, it has promoted demands of administrative decentralisation, in return, paving the way for the creation of new districts and sub-divisions.

\section{(2) Electoral Competition: Politics and District Administration}

The impact of Local Bodies elections was that local issues (i.e., caste, biradri rivalry, seeking patronage for developmental grants and schemes) acquired political salience. Thus, the military regime curbed politics at the national level but facilitated non-party electoral competition at the local level. Therefore, the politicians and new entrants to politics began to work for creating greater autonomy for themselves and demanded creation of new districts. In 1982, two new divisions, Faisalabad and Gujranwala were created in the Punjab. Subsequently, (between 1982-1988), Rajanpur, Leiah, Bhakkar, Khanewal, Khushab, Toba Tek Singh, Okara and Chakwal were created as new districts. In the post-1988 period, Lodhran, Mandi Bahauddin, Pakpattan, Hafizabad, Narowal were made new districts. Similarly Gujrat was transferred from Rawalpindi Division to Gujranwala Division.

In the rural setting and administrative structure of Pakistan, district is the primary unit of administration. Since 70 percent of the constituencies are rural, political, economic and administrative activity revolves around the district. A hundred years ago, writing in 1892, this is how W. W. Hunter described the pivotal role of the Deputy Commissioner for the British Raj:

Upon his energy and personal character depends ultimately the efficiency of our Indian government. His own special duties are too numerous and so various as to bewilder the outsider.

He is a fiscal officer, charged with the collection of revenue from the land and other sources; he also is a revenue and criminal judge, both of first instance and appeal. But his title by no means exhausts his multifarious 
duties. He does in his smaller local sphere all that the Home Secretary Superintendent in England, and a great deal more; for he is the representative of paternal and not of a constitutional government. Police, jails, education, municipalities, roads, sanitation, dispensaries, the local taxation, and the imperial revenues of his District are to him matters of daily concern. He is expected to make himself acquainted with every phase of the social life of the natives, and with each natural aspect of the country. He should be a lawyer, an accountant, a surveyor, and a ready writer of state papers. He ought also to possess no mean knowledge of agriculture, political economy, and engineering.

Could one seriously expect the Deputy Commissioner to perform these multifarious tasks in today's Pakistan? During the British Raj and early years of Pakistan, the District Officer performed all the traditional roles of a Deputy Commissioner i.e. a revenue collector, administrator, a magistrate, a development planner and a patron of the district. However, with expansion of political process, these functions of the district officer underwent change as elected public officials begun to establish their supremacy. The local councillors, the members of provincial assemblies, and the national assembly became more assertive about advancing their self-interests and at times interests of their constituents. The elected public officials insist to control and regulate the social and political life in their districts. If and when district administration does not comply with their demands, they seek posting and transfers of the officers. This clearly demonstrates that district continues to be the pivot of political and administrative interaction.

It is not merely influence with the District Administration that the politicians seek, but to consolidate structural presence, they also seek appointments in the district administration. The Local Councillors, Members of National and Provincial Assemblies (MNA/MPAs) demand recruitment of their relatives or supporters for the appointment of Tehsildars/Naib Tehsildars, Inspector/Sub Inspectors of Police, school teachers, lady health visitors, and petty clerks. In Punjab, between 1985-1990, an estimated 2000 Assistant Inspectors of Police, Tehsildars, Naib Tehsildars were recruited [The Friday Times (1997)]. These appointments were made either on the recommendations of the Chief Minister or parliamentarians. This practice has continued; its pace and scale has increased since 1990. Each successive government, whether belonging to the PPP, the PML (N), caretaker or coalition, has continued this practice. Resultantly, democratisation has strengthened the paternalistic model of administration rather than constitutional government. The current chief minister, Shahbaz Sharif has brought about a change. He has revived and reactivated the Punjab Public Service Commission (PPSC) for recruitments in the Punjab Police and administration. In the provinces of Sindh, Balochistan and NWFP, similar practices of creating new districts and recruitment of subordinate administrative class were pursued and continue to be in vogue. Through these devices, the political parties and 
their parliamentary leaders, have built a structural presence in the provincial administration.

Interestingly, the mystique of the office of the Deputy Commissioner persists but its glory and reputation have been tarnished, functioning undermined, and authority eroded. The donor agencies like the World Bank, IMF, UNDP and other Reform Commissions, when they suggest that the Office of Deputy Commissioner be abolished, they fail to comprehend that district as an administrative unit and Deputy Commissioner as the administrator complement each other. How can you demolish the post of Deputy Commissioner, without dismantling the district? Unless a new basis for an administrative unit is created, the deputy commissioner would not only continue to be relevant but will remain the principal coordinating officer not only of the district, but also as the primary arm of the provincial government and a basic link with the federation.

As a result of this changing nature of relationship between the politician and the bureaucrat, democracy has considerably eroded the authority of the administrative institutions. The politics of patronage has promoted corruption, and recruitment of henchmen of politicians has strengthened the authoritarian streaks in the existing feudal social order. Furthermore, democratisation has led to the development of illiberal tendencies, partisanship, lack of tolerance and distrust in the fairness of administration. These have been the negative fall out effects of democratisation. Unless, "constitutional government" is allowed supremacy over "paternal government", democratisation would breed politicisation, maladministration, impartiality, corruption and deepen the crisis of governance.

\section{(3) Behavioural Pattern of Political Leadership and Socio-economic Profile of the Parliamentarians}

In a democratic system, the political leadership is expected to coordinate between the expectations and demands of its support groups and the groups that are not fully supportive of their leadership [Weingast (1997)]. The task of the leadership is to establish a framework on the basis of which uniform and credible principles of political game may evolve. Pakistani experience reveals a two-fold predicament. First, a growing disharmony between the political leadership's professed democratic creed and authoritarian policies and practices. This disharmony has considerably damaged the sustainability of democracy.

Secondly, political leadership in Pakistan reveals a coordination dilemma. On the one hand it aspired, and in some cases, has struggled to restore democracy, espoused greater participation of masses into political process, promised to build constitutionalism, promote liberal democracy, uphold rule of law and, yet, in its conduct and behaviour portrays an equally strong dispensation towards autocratic tendencies. 
Let me exemplify some of these contradictions. In the 1970s, Zulfikar Ali Bhutto rose to political eminence portraying himself and perceived by the public as a democrat. He was inducted into Ayub Khan's military regime, and remained associated with it from 1958-1966. He disassociated himself from the regime and recreated an image for himself and founded Pakistan People's Party (PPP) in November 1967. Through mass mobilisation, 'socialist' ideology and organisational network, the PPP was developed into a national party. Bhutto did not encourage elections within the party; instead, he nominated persons to the membership of the central executive committees and various other levels—national, provincial, local. The membership of the party expanded, but organisational structure was kept weak and under personal control [Syed (1992)]. On assuming power, Zulfikar Ali Bhutto (1971-77) was skillful and successful in formulating and adopting a constitution for Pakistan through parliamentary consensus. However, his personal conduct and political style contributed little in promoting rule of law. He could not curb his authoritarian propensities, when through a series of constitutional amendments, he restricted freedom of judiciary, freedom of press, and even freedom of religion (i.e., in 1974 Ahmedis were declared a minority). The attitude and behaviour of opposition political parties was equally hostile and confrontational. The government and opposition leaders demonstrated a coordination dilemma - they failed to iron out their differences, on the functioning of parliamentary democracy. These disabilities of political leaders, encouraged the military to disrupt the fragile quasi-democratic set up.

General Zia's rule (1977-1988) weakened the civil society; participatory processes, democratic norms and values were further mutilated. Political parties endured, but their organisational capacity was restricted. The military rule, though harsh on civil and religious freedoms, could not suppress democratic aspirations among the public. Therefore, underneath his autocratic rule, tension between prodemocracy and anti-democracy forces persisted. General Zia-ul-Haq was skillful in encouraging and expanding the base of religious groups, trader-merchants and other right-wing groups [Shafqat (1997)]. In 1981, political leaders with feudal background and support base, along with urban professionals, launched a prodemocracy alliance - the Movement for Restoration of Democracy (MRD). The MRD demanded removal of martial law and called for holding of elections. These demands eventually paved the way for restoration of democracy in 1985. Mohammed Khan Junejo, who was handpicked by Zia-ul-Haq as prime minister (1985-1988), demonstrated democratic dispensation, and allowed the return of Benazir Bhutto to Pakistan. He also promoted an environment in which opposition political parties could function. Simultaneously, Junejo revealed a strong propensity to establish the dominance of Muslim League. He introduced a scheme of granting developmental funds to the members of the parliament, essentially those of his own party, for development and welfare purposes in their constituencies. He was modestly successful in creating a framework for government-opposition 
relationship. Before he could stabilise party rule and processes of democratic institution-building, he was removed. Muhammad Khan Junejo is not given the credit that he deserves. Among the political leaders, he stands out as a prime minister who showed tolerance towards opposition political parties, showed respect for rule of law and encouraged an environment for the freedom of press and above all created space for consensus-building.

From 1988 to 1998, Benazir Bhutto and Nawaz Sharif, who, in many ways, represent a new generation of leaders, created an expectation for democratic rule. Both in their own ways restored and reorganised their respective political parties, i.e., PPP and PML (N). Both created expectation about upholding the rule of law. As opposition leaders, in a limited way, they contributed towards expansion of democratic processes. But both have shown strong, autocratic tendencies, as soon as they assumed power. Instead of upholding the rule of law, both have flouted it, both have shown little respect for minority rights and views, both have suppressed dissent and restricted opposition. Both have made little effort in engaging the opposition parties and government into a dialogue and create conditions for consensus-building. Through incongrument policies and bad laws, both have encouraged social attitudes that promote undemocratic norms rather than building mutual trust, accommodation and dialogue.

Both PPP and PML (N) continue to be the dominant political parties, and share almost 62 percent of the total votes polled in various elections (see Table1). Both have preferred to establish a dominant party system rather than encouraging the growth of a two party system. Both have deepened crisis of governance and polarised the society (see the voting percent of both). Prime Minister, Nawaz Sharif has a unique opportunity to engage opposition political parties in a dialogue on issues of vital national significance and promote an environment of national healing, reconciliation and consensus building. Failure to act now could intensify social disharmony and political violence.

Table 1

Party Share of Votes: All-Pakistan National Assembly Elections

\begin{tabular}{|c|c|c|c|c|c|c|c|c|}
\hline & \multicolumn{2}{|c|}{1988} & \multicolumn{2}{|c|}{1990} & \multicolumn{2}{|c|}{1993} & \multicolumn{2}{|c|}{1997} \\
\hline & $\begin{array}{l}\text { \% of } \\
\text { Votes }\end{array}$ & $\begin{array}{l}\text { No. of } \\
\text { Seats }\end{array}$ & $\begin{array}{l}\% \text { of } \\
\text { Votes }\end{array}$ & $\begin{array}{l}\text { No. of } \\
\text { Seats }\end{array}$ & $\begin{array}{l}\text { \% of } \\
\text { Votes }\end{array}$ & $\begin{array}{l}\text { No. of } \\
\text { Seats }\end{array}$ & $\begin{array}{l}\% \text { of } \\
\text { Votes }\end{array}$ & $\begin{array}{l}\text { No. of } \\
\text { Seats }\end{array}$ \\
\hline PML (N)/IJI & 30.16 & 54 & 37.37 & 106 & 39.86 & 72 & 45.88 & 134 \\
\hline PPP/PDA & 38.52 & 93 & 36.83 & 44 & 37.85 & 86 & 21.80 & 18 \\
\hline MQM & 5.37 & 13 & 5.54 & 15 & - & - & 3.55 & 12 \\
\hline JUI (F) & 1.84 & 7 & 2.94 & 6 & 2.4 & 4 & 1.61 & 2 \\
\hline ANP & 2.09 & 2 & 1.68 & 6 & 1.67 & 3 & 2.31 & 9 \\
\hline JWP/BNA & 0.36 & 2 & 0.61 & 2 & 0.27 & 2 & 0.29 & 2 \\
\hline BNP & - & - & - & - & - & - & 0.66 & 3 \\
\hline PKMA/PMAI & 0.24 & 0 & 0.35 & 1 & 0.49 & 3 & 0.33 & 0 \\
\hline Others & 1.92 & 6 & 4.38 & 5 & 12.46 & 21 & 9.2 & 2 \\
\hline IND & 19.50 & 27 & 10.30 & 22 & 7.40 & 15 & 14.37 & 22 \\
\hline & 100 & 204 & 100 & 207 & 100 & 202 & 100 & 204 \\
\hline
\end{tabular}

Source: The Herald, March 1997. 
Is the electoral contestation fair and provide equal opportunity to all contesting groups? The experience of Pakistan reveals that, whereas electoral process, at least theoretically, provides equal opportunity to all citizens to seek a public office, but in reality landlords/tribal leaders, big business and religious leaders tend to be the primary contestants.

The data of five elections from 1985 to 1997, reveals that the representation of various classes and groups has shown some increase, but feudals/tribal leaders still continue to be the dominant class. Out of a total of 207 seats for the National Assembly (NA), they continue to retain on an average 125 seats. In the five elections, urban professionals (i.e. lawyers, doctors, technocrats), on the average, have been able to win 26 , while businessmen/industrialists 38 seats. This is a healthy trend, but it does not reflect a corresponding behavioural change in the attitude of parliamentarians. The feudal norms and attitude continues to influence the behavioural pattern of the parliamentarians (see Table 2). A comprehensive data on the educational background of the members of the NA is not available. A sizeable number of 207 members of the NA do not have formal schooling. A small number, about ten percent, are proficient in English, while a larger majority (i.e. 95 percent) is conversant with Urdu.

I have been able to collect some data on the composition of federal cabinets from 1985 to 1997. It reveals that, feudals, lawyers/professionals and business groups continue to dominate the federal cabinet. In the Junejo cabinet, feudals, lawyers/professionals and business groups were evenly spread. Therefore, in terms of social group representation, his cabinet could be considered most representative. The first Benazir cabinet, (1988-1990), was dominated by feudals and lawyers/professionals. The second Benazir cabinet, (1993-1996), was overwhelmingly dominated by the feudals. It is interesting to note that the middle classes, which are not adequately represented in the NA were equally underrepresented in the Benazir cabinets. While, Nawaz Sharif's cabinet, (1990-1993), was dominated by business groups (9), lawyers/professionals (12) and the feudals

Table 2

\begin{tabular}{lrrrrr}
\multicolumn{5}{c}{ Social Class Background of National Assembly Members } \\
\hline \multicolumn{1}{c}{1985} & 1988 & 1990 & 1993 & 1997 \\
\hline Landlords and Tribal Leaders & 157 & 156 & 106 & 129 & 126 \\
Businessmen/Industrialists & 54 & 20 & 38 & 37 & 39 \\
Urban Professionals & 18 & 9 & 46 & 26 & 32 \\
Religious Leaders & 6 & 15 & 11 & 8 & 3 \\
Retired Military Officers & - & 7 & 3 & 5 & 2 \\
Others & 3 & - & 3 & 3 & 2 \\
& & 207 & 207 & 207 & 207 \\
\hline
\end{tabular}

Source: Compiled by Saeed Shafqat. 
(12) were significantly represented. The second Nawaz Sharif cabinet, (1997-98), is extremely narrow-based. It is overwhelmingly dominated by professionals and business groups, and the size of feudals is significant. However, representation of middle classes has remained marginal in all the federal government cabinets from 1985-1998 (see Table 3). The feudal/tribal social origins of the parliamentarians and their dominance in the federal cabinets reveals feeble commitment towards democratic norms. Thus processes that could promote mutual trust, accommodation, respect for dissent and consensus building — remain under developed.

Not only the interpersonal trust is weak among the parliamentarians but they are also inadequately informed about the rules and procedures of parliamentary practice. They pay little attention to develop the National Assembly into a forum for discussing national issues and formulation of legislation. Parliamentary parties and their leadership has paid little attention towards developing their position on specific issues.

During 13 years of parliamentary democracy 1985-1998, the NA not only held fewer sessions but its legislative performance has also been dismal. During the first Benazir Bhutto government, frequency of sessions was so low that only 11 meetings were held. During her second tenure, the number of sessions rose to only 31. During Nawaz Sharif's first term, the NA held 17 Sessions. During his 2nd term, 20 sessions have been held. Duration of these sessions was short. It is plausible that either the NA did too little or had no legislative work. During Junejo's government, parliament held longer sessions, shows that it met for debate and also did some legislative work (see Table 4).

Table 3

Composition of Cabinets 1985-1998: Federal Ministries and Ministers of State

\begin{tabular}{|c|c|c|c|c|c|c|c|c|c|}
\hline & Feudals & Business & $\begin{array}{c}\text { Lawyers/ } \\
\text { Professionals }\end{array}$ & Generals & Women & Ulema & Minorities & Unidentified & Total \\
\hline & & & & & & & & & 27 \\
\hline \multicolumn{10}{|c|}{ M.K. Junejo } \\
\hline \multirow[t]{2}{*}{ 1985-88 } & 12 & 3 & 8 & 2 & 1 & 1 & - & - & \\
\hline & & & & & & & & & 44 \\
\hline \multicolumn{10}{|c|}{ Benazir Bhutto } \\
\hline \multirow[t]{2}{*}{ 1988-90 } & 15 & 1 & 14 & 3 & 4 & - & 1 & 6 & \\
\hline & & & & & & & & & 39 \\
\hline \multicolumn{10}{|c|}{ Nawaz Sharif } \\
\hline \multirow[t]{2}{*}{ 1990-93 } & 12 & 9 & 12 & 1 & - & 1 & 2 & 2 & \\
\hline & & & & & & & & & 39 \\
\hline \multicolumn{10}{|c|}{ Benazir Bhutto } \\
\hline 1993-96 & 17 & 3 & 13 & 2 & 1 & - & 1 & 2 & \\
\hline \multicolumn{10}{|c|}{ Nawaz Sharif } \\
\hline 1997 & 8 & 6 & 8 & 1 & 2 & - & - & 1 & 26 \\
\hline
\end{tabular}


Table 4

\begin{tabular}{lccc}
\hline $\begin{array}{l}\text { Parliamentary Government } \\
1985-1998\end{array}$ & $\begin{array}{c}\text { National Assembly } \\
\text { Sessions }\end{array}$ & $\begin{array}{c}\text { Total } \\
\text { Days }\end{array}$ & $\begin{array}{c}\text { Average Duration } \\
\text { Days }\end{array}$ \\
\hline $\begin{array}{l}\text { Mohammad Khan Junejo } \\
\text { P.M. 1985-88 }\end{array}$ & 15 & 545 & 36 \\
$\begin{array}{l}\text { Benazir Bhutto } \\
\text { P.M. 1988-90 }\end{array}$ & 11 & 218 & 20 \\
$\begin{array}{l}\text { Nawaz Sharif } \\
\begin{array}{l}\text { P. M. 1990-93 } \\
\text { Benazir Bhutto }\end{array}\end{array}$ & 17 & 417 & 25 \\
$\begin{array}{l}\text { P.M. 1993-96 } \\
\text { Nawaz Sharif }\end{array}$ & 31 & 525 & 17 Days \\
P. M. Feb. 1997 - March 1998 & 20 & 140 & 7 Days \\
\hline
\end{tabular}

Source: Secretary, National Assembly, Islamabad. Compiled by Saeed Shafqat.

From the above analysis, it is evident that the NA has not been able to develop into a forum, which may inform, educate and reflect the opinion of citizens or representative interest groups. Parliamentarians have made little effort to develop consensus on important legislation. Invariably, it is through Ordinance, rather than through debate, that the legislation, if any, has been adopted. The parliamentarians and political parties have not been able to bring diverse and divergent interests and issues for debate and resolution in the NA. Therefore, extra-parliamentary tactics continue to dominate Pakistani politics. Major national issues are debated and managed outside the parliament (over the years, no meaningful discussion on Kashmir, sectarian problem or India's nuclear explosion etc. has taken place in the NA). Thus, NA has not been able to develop as an institution that could promote and strengthen democratic norms and practices. If parliamentary democracy has to succeed, regular sessions of the assembly, greater debate, more legislative work needs to be created to enhance the capacity of the NA.

\section{(4) Political Parties and Challenges of Democratic Development}

Pakistan has been struggling to sustain political parties as an instrument of interest representation and popular will. In the past 51 years, political parties have endured, (despite Martial Laws and other Presidential interventions). Political parties remain instruments of patronage and mass mobilisation. The political parties have yet to acquire the skills of interest representation in the parliament. Given mass mobilisation orientation, the political leadership uses political parties for street demonstration and politics of agitation. So political parties have developed and grown into effective tools for extra-parliamentary politics, but they continue to have limited utility for promoting democratic norms and performing legislative/rule making functions in the parliament. The challenge for the party leadership in 
Pakistan is to transform the character of political party from an instrument of mass mobilisation to interest representation and advocacy in the parliament.

An outstanding feature of party politics in Pakistan has been the making and breaking of alliances and coalitions. However, coalition-building within the parliament has remained weak and inconsistent. Bipartisan or multi-party consensus on a particular issue has rarely developed. (Recently, on two occasions political parties have demonstrated consensus, first, on removing the Eighth Amendment and passing 13th Amendment. Second, adopting a Bill revising the salary and pay structure of the MNAs.) The opposition parties and the government (party in power) instead of engaging in a dialogue, and developing a national consensus indulge in politics of hostility and confrontation. The party in power invariably seeks to exclude opposition parties and attempts to establish dominance. In turn, the opposition parties, venture to build an extra-parliamentary alliance, simultaneously they attempt to resort to street protest and mass mobilisation against the government. Their basic aim is to dislodge the government rather than engage in dialogue. (For example, Democratic Action Committee (DAC) 1968, Pakistan National Alliance (PNA) 1977, Movement for the Restoration of Democracy (MRD) 1983, Islami Jamhuri Ittehad (IJI) 1988 and Pakistan Awami Tehrik, (PAT) 1998.) Invariably, such coalitions are built only because the opposition political parties are inadequately represented in the NA, and thus, they have little stake in the parliament. They pressurise the government or the president to dissolve the assembly. Since 1988 (i.e. removal of Junejo government), there is evidence to suggest that the military and the president have acted in concert to dislodge the elected governments in 1990 and 1993. In 1996, the president and the judiciary were perceived by the public as playing a critical role in the dismissal of the Benazir government.

Despite making struggle for the restoration of democracy, political leaders, élites and interest groups, have failed to build a legal framework, create a prodemocracy environment, and most importantly, develop a policy framework in which conflicts may be resolved inside the parliament. Ironically the parliamentarians adopt policies that strengthen authoritarian attitudes rather than promote democratic norms, respect for law or tolerance of any political opposition. For example, the current Nawaz Sharif government has passed legislation in haste that curtailed the powers of the president, passed anti-defection clause that bound members to party discipline. Even the PML $(\mathrm{N})$ party leadership did not discourage supporters to attack the Supreme Court building in November 1997. The formation of Khidmat Committees, Ehtsab Cell and Open Kutcheries are some of the methods that show authoritarian tendencies and weaken the position of representative institutions.

The political parties of Pakistan are witnessing a decline, if not death of the militant party worker. In the late 1960s and early 1970s, political parties needed and dependent on militant party workers, who were ideologically motivated, dedicated, 
campaigned for party, raised funds, organised the workers in a factory or supporters in the Mohalla, put up party posters, advocated party line or ideology. They kept the party organisation intact, and provided a certain social service. In the 1990s, this has changed, a militant worker or a party "Jiala" has declined. He has been replaced by a media advisor, who portrays the programme, image, slogans of the party through electronic and print media. Party worker has been replaced by image-builder for the party and its leaders. There is growing tendency among the top ranking party leadership to fax statement to the newspapers rather than focus on building the grass root organisation of the party.

\section{CONCLUSION AND POLICY OPTIONS}

From the foregoing analysis, it is evident that the results of Pakistan's experimentation with parliamentary democracy (particularly for the last 13 years) are mixed. Several contradictory trends are noteworthy. First, political leaders continue to reveal lack of commitment to the principles of democracy and, above all, have found it difficult to develop the National Assembly as the primary forum for national debate, dialogue and legislation. To make parliamentary democracy succeed, the parliamentarians need to strengthen the parliament. Confidence in electoral competition has to be matched by parliamentary performance. The challenge for the parliamentarians is to enhance the legislative and consensus building capacity of the NA.

Secondly, significant transformation in the electoral competition has led to the integration of a number of regional parties, like ANP, BNP, MQM, JWP and BNA with the national political system. This has diffused separatist tendencies and encouraged confidence in the democratic process. The smaller provinces are more demanding and assertive to expand their share in the federal structure. Transition to democracy has strengthened the federal character of Pakistani state. This has given boost to devolution of administrative authority. Electoral process has accelerated the pace for such a change at the provincial level. After each election, the structural presence of the elected officials has gained ground. However, there are two negative fall out effects: (i) partisanship has compromised the neutrality and fairness of administrative institutions; and (ii) the majoritarian view of democracy of the ruling party has roused skepticism among the smaller provinces. Unless these actions are reversed or resolved through deliberations, it could further deepen the crisis of governance.

Thirdly, there is a growing awareness among the public that dynastic character of the political parties is an obstacle for the development of democracy and party system. In recent years, some muted voices of reform from within the political parties have also appeared but with little effect. The challenge for the leadership, both in the government and the opposition, is to reform and democratise the structures of political parties. Reformed and democratised political parties are the best guarantee for a democratic order, its continuity and stability. 
Fourthly, global trend towards democratisation, has restricted the possibility of direct military intervention, although, apparently, from a distance, the military will continue to monitor and influence the direction of political process. Therefore, in the foreseeable future, Pakistan's transition to democracy will endure pain, occasional violence, conflict and corruption. This is worrisome and not a good omen for consolidation of democracy.

Fifthly, the growth and expansion of print media is the most positive outcome of democratisation, it augurs well for democratic consolidation in the country. Freedom of the press is a irreversible trend and lends support to continued sustenance of democratic process in the country.

Finally, democracy has become an expensive form of government. The 1985 election costed the Government of Pakistan around 17 crore rupees (170 Million). In 1993, the cost had risen to 41 crore rupees (410 Millions). In 1988, on an average a candidate contesting for the National Assembly seat spent around Rs 5 Lakh (.5 Million). In the 1997 election, cost of NA seat had risen to Rs 50 Lakh (5 Million). This suggests that only big landlords, businessmen and, in few cases, urban professionals could contest elections. In order to sustain and consolidate democracy and encourage the representation of middle classes, the costs of electoral competition need to be lowered. There are signs of discontent of middle classes in the urban centres, where resentment is growing against the ineffectiveness of democratically elected government to provide justice and security to citizens. Failure to meet this challenge, could deepen crisis of governance and cause social upheaval, anarchy and mass agitation.

This can be averted through a concerted effort on the part of government and opposition political parties to engage in a dialogue on the broader goal of how to sustain and build democratic institutions? Democracy in Pakistan is at cross roads and a future vision demands building consensus on the following:

(1) continuity of free and fair elections;

(2) rights of the political opposition to operate without restrictions by curtailing the arbitrary powers of the state especially through extra-judicial killings, torture under detention, etc;

(3) protection of minorities and civil liberties;

(4) security of citizens' life and promote conditions that improve quality of individual;

(5) an independent judiciary to check state power; and

(6) an agenda for bipartisan consensus on social and economic policies.

All these objectives may not necessarily be achieved at the same time or in a certain sequence; some may prove to be more difficult than others. Some may even prove to be elusive in the end. But there is no short-cut to democracy and democratisation of state and society. If we have to develop into a viable democratic society, we have to move in the right direction and sooner the better. 


\section{REFERENCES}

Afzal, M. Rafique (1976) Political Parties in Pakistan, 1947-1959. Islamabad: National Commission on Historical and Cultural Research.

Ahmed, Mushtaq (1987) Politics of Crisis. Karachi: Royal Book Company.

Callard, Keith (1957) Pakistan: A Political Study. London: Allen George and Unwin.

Diamond, Larry, Juan J. Linz, and Seymour Martin Lipsel (ed) (1989) Democracy in Developing Countries, Asia. Vol. 3, Boulder, Co: Lynne Rienner Publisher.

Embree, Ainslie (1997) Statehood in South Asia. Journal of International Affairs. 51:1, Summer. 10-15, 1-18.

Evans, Hugh D., and Leo E. Rose (1997) Pakistan's Enduring Experiment. Journal of Democracy 8:1 83-96.

Gardezi, Hasan Jamil Rashid (ed) (1983) Pakistan: The Roots of Dictatorship. London: Zed Press.

Hunter, W. W. (1892) The Indian Empire: Its People, History and Products. London: Smith, Elder. 513-514.

Inayatullah, Sohail (1997) The Futures of Democracy in Pakistan-A Liberal Perspective. Futures 29:10 955-970.

Jalal, Ayesha (1995) Democracy and Authoritarianism in South Asia: A Comparative and Historical Perspective. Lahore: Sang-e-Meel Publications. 925, 48-62.

Kennedy, Charles (1987) Bureaucracy in Pakistan. Karachi: Oxford University Press. 54-87.

Rasul, Rais B. (ed) (1997) State, Society and Democracy in Pakistan. Karachi: Oxford University Press.

Rizvi, Askari Hasan (1997) The Military and Politics in Pakistan 1947-86. Lahore: Progressive Publishers.

Several Issues of Debates: The National Assembly of Pakistan, Karachi, The Manager Publications. These official reports are published regularly and are obtainable from Government of Pakistan from 1980 to 1997.

Shafqat, Saeed (1997) Civil-Military Relations in Pakistan. Boulder: Westview Press. 184-219.

Syed, H. Anwar (1992) The Discourse and Politics of Zulfikar Ali Bhutto. London: MacMillan. 205-230.

Taylor, David (1992) Parties, Elections and Democracy in Pakistan. Journal of Commonwealth and Comparative Politics 30:1 96-115.

The Friday Times (1997) Lahore, August 22-28.

The Nation (1994) Lahore, July 4.

Waseem, Muhammad (1989) Politics and the State in Pakistan. Lahore: Progressive Publisher. 
Waseem, Muhammad (1993) The 1993 Elections in Pakistan. Lahore: Vanguard.

Weingast, A. Barry (1997) The Political Foundations of Democracy and the Rule of Law. American Political Science Review 91:2 (June) 245-263.

Wilder, R. Andrew (1995) Punjab Politics in Pakistan: National Assembly Election Results, 1988-1993. Asian Survey 35:6 377-393. 